\title{
Fashion and the Future
}

\author{
Lawrence J Udell*
}

New Mexico Tech, USA

*Corresponding author: Lawrence J Udell, Adjunct Faculty, Business and Technology Management, USA.

Received Date: May 01, 2020

Published Date: May 08, 2020

\section{Opinion}

Let us look at the fashion industry and the remarkable transition of what we wear today as compared to 10, 20, 50 years ago. By examining the various materials used in all forms of clothing we see both similarities from the past and yet the new textiles that have emerged from research labs across the world. Also, the influence of cultures on fashion and how certain societies have changed their garments over the decades.

The textile industry is an ever-growing market, with key competitors being China, the European Union, the United States, and India. China is the world's leading producer and exporter of both raw textiles and garments. The United States is the leading producer and exporter of raw cotton, while also being the top importer of raw textiles and garments.

Textiles are classified according to their component fibers into silk, wool, linen, cotton, such synthetic fibers as rayon, nylon, and polyesters, and some inorganic fibers, such as cloth of gold, glass fiber, and asbestos cloth.

The U.S. textile and apparel industry is a nearly $\$ 70$ billion sector when measured by value of industry shipments. It remains one of the most significant sectors of the manufacturing industry and ranks among the top markets in the world by export value: $\$ 23$ billion in 2018.

If you look at the influences on the fashion industry it is dominated by a hand full of designers who not only control the imagination of the viewers but also the lock they have on young designers with creativity and untold amounts of imagination. My personal involvement in the industry was about ten years ago when a wealthy female friend of mine and her two close girlfriends wanted to design bathing suits. They discovered by applying a special fabric to the material provided a slimming effect. She approached me for the purpose of how you protect new designs but also as a judge of what they create. I found this challenge to be one of the most interesting in my entrepreneurial life. The first thing I did was to clarify my position and potential compensation, so we all had a clear understanding of our future relationship.

I then contacted a dear friend of mine who was a Director of the Fashion Institute in New York City. We arranged for her to come out to the Bay Area for two days and meet with the team. It was both an interesting experience and one where I was able to provide my ideas and concepts into the designs.

This fun time was totally based on the original partner and her financing the venture. She was divorced and lived in a home in Pleasant Hill, CA which became our studio.

To the best of my memory the whole opportunity fell apart when she found the "love of her life" and they decided to move to a remote area of the State, and we all gave up on the program. To this day I do not know where all the participants went but do know my New York friend retired and my last contact with her about five years ago she was enjoying life.

All you need to do is look at magazines that have photos of not only beautiful women and handsome men, but articles on fashions and who is creating them. All the retailers from Target to Nordstrom's are always releasing new and some of their most popular designer items from the past 20 years. Lilly Pulitzer, Missoni, Jason $\mathrm{Wu}$, and more. The textile and fashion industry are here to stay and will continue to grow as the population and demand continues to increase. It will continue to be influenced depending on what celebrity is wearing what and the viewer and their wallet.

Let us look at the Intellectual Property involved in the industry which is critical to the financial results of the designers and creators of the products. 
Fashion designers most often file design patents for their creations and the clothing manufacturers will often patent a unique design to prevent other companies from imitating it. If you hold design patent rights, you could sell or license them to a clothing company. If your apparel has unique functions to it, you could also patent those functions with a utility patent.

Patent filing costs vary widely, from about $\$ 200$ for a very small company's design patent to upwards of $\$ 5,000$ for a complex utility patent. Designers can obtain protection for their fashion designs by applying for a design patent. Design patents protect the look of a design, or ornamentation, if it is novel, non-functional and nonobvious to a designer of ordinary skill in the art. Only a design patent provides complete protection to call a design all your own. If you have put off filing patents due to lack of time, look to some of your big fashion heroes in this business.

Many of the most influential fashion designers in the world now patent their designs to avoid having to spend time in a courtroom rather than creating. Brand names like Yves Saint Laurent filed eight fashion design patents last year. They applied these to new handbag designs, as well as for a special brand of heels they designed.

Also, Louis Vuitton filed four new patent designs last summer for their unique handbags. Other names joining these include Bottega Veneta and Balenciaga. With these names, their attention to patents benefits them exponentially since many of their creations become brand staples.

It is here where a fashion design patent can become beneficial to not only the big names, but also smaller ones. Protection length is quite significant, despite making a huge difference in when you file. Fashion designers face a unique set of challenges in protecting their intellectual property. Though a fanciful garment may be the result of a single creative process by the designer, a designer or manufacturer may need to use multiple forms of intellectual property to fully protect the fashion design of that garment. The law has now shifted in a way that makes copyright law more useful for fashion article designers and manufacturers, however, a recent U.S. Supreme Court decision has clarified and expanded how copyright law can be leveraged to protect certain aspects of fashion design. The U.S. Copyright Act of 1976 provides protection for "the design of a useful article" in circumstances where designs "can be identified separately from, and are capable of existing independently of, the utilitarian aspects of the article." Historically, it has been difficult to protect clothing designs, including patterns, under United States copyright law because courts have considered clothing designs as part of the utilitarian purpose of clothing. We wear clothes in part because they make us look good, and thus clothing design aesthetic is part of the utility of the clothing, or so the prevailing argument has gone.

IP law has played an enormous role in the proliferation of fashion. Take runways, for example; very few designs on display are sold in stores. The runway is an opportunity for designers to display their creative talent, attract media attention and build awareness of their brand. They also provide an opportunity for a brand to sell more affordable items, such as perfumes, cosmetics or T-shirts, with brand names prominently displayed on them. So much of the fashion industry thrives on this type of IP licensing. IP is a core asset of the fashion business. In the United States, we talk a lot about copyright law as the main source of protection for designs and its interaction with fashion. But trademarks are really the most widely used means by which fashion brands protect themselves in the United States.

The Patent Act provides the legal basis for design patent protection in the United States. Anyone who invents a new or original ornamental design for a commercial article is entitled to patent protection subject to the terms and conditions of the Patent Act. Unlike utility patents, design patents protect the "look" of an object, not its function. Typically design patents are granted within a year and their protection lasts for 14 years.

You may wonder if you need to trademark or copyright your clothing line. Your company's name can be trademarked because it is a unique name and logo. A copyright, however, protects a piece of creative work or authorship and so cannot be used for a brand name.

Trademarking the name of your clothing line is a good idea because it ensures no one else can use it. Your name will remain unique and protected. If you are wondering how to patent a clothing line name, the answer is you cannot. The name can be trademarked, not patented.

Your brand's name and logo are key in developing a distinctive identity and in protecting your work. You want to select a name for your clothing line that is unique yet speaks to you in some way. Start by searching online to make sure no one else is using the name you have chosen. Perform a general web search as well as one on the U.S. Patent and Trademark Office website. Next, develop a unique brand logo that uses the name and incorporates a unique combination of design, font, size, and color.

Once you have settled on a name and design for the logo, you will want to trademark it with your state. Complete the application with your state and pay the fee. The state process is faster than the federal process and sets out some ownership rights for you immediately.

Next, you need to file an application for the trademark with the U.S. Patent and Trademark Office, which entails completing a form, paying a fee, and waiting up to six months. Once it is trademarked, no one else can use that name or design. Take the time to look up the hundreds of trademarks that protect fashion, from shoes to handbags.

In conclusion, if you are part of this fascinating and creative industry make every attempt to be different and to create a brand that will be recognized all over the world. 


\section{Acknowledgement}

None.

\section{Conflict of Interest}

None.

\section{About Author}

Larry Udell is the founder and Chairman of the California Invention Centre created at California State University in 1995. He has taught courses on New Ventures for over 40 years at universities throughout the United States and in foreign countries for WIPO (United Nations). A member of the Licensing Executives Society since 1982, he founded the Silicon Valley Chapter in 2000. Professor Udell provides consulting to both start-ups and Fortune 500 companies, and lectures frequently at inventor, corporate and government functions throughout the United States. He is the founder and President of Intellectual Properties International and Vice President of American Innovators for Patent Reform besides serving as Senior Consultant to General Patent Corporation. He also serves as a corporate officer and board member of companies and in his illustrious long career has mentored hundreds of inventors and new ventures.

Email ID: larry@les-svc.org 